\title{
20: 31737854-31727150
}

National Cancer Institute

\section{Source}

National Cancer Institute. 20:31737854-31727150. NCI Thesaurus. Code C42156.

Physical location of E2F1_Gene 